\title{
Yield per recruit of the peacock bass Cichla monoculus (Spix and Agassiz, 1831) caught in Lago Grande at Manacapuru (Amazonas - Brazil)
}

\author{
Campos, CP. ${ }^{* *}$ and Freitas, CEC. ${ }^{b}$ \\ anstituto Nacional de Pesquisas da Amazônia - INPA, Av. André Araújo, 2936, Aleixo, \\ CEP 69060-001, Manaus, AM, Brazil

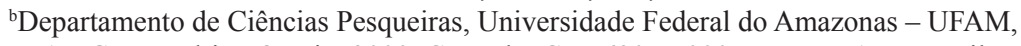 \\ Av. Gen. Rodrigo Otávio, 3000, Coroado, CEP 69077-000, Manaus, AM, Brazil \\ *e-mail: krolpc@gmail.com
}

Received: August 21, 2012 - Accepted: January 18, 2013 - Distributed: February 28, 2014

(With 3 figures)

\begin{abstract}
We evaluated the stock of peacock bass Cichla monoculus caught by a small-scale fishing fleet in Lago Grande at Manacapuru. The database was constructed by monthly samplings of 200 fish between February 2007 and January 2008. We measured the total length $(\mathrm{cm})$ and total weight (gr) of each fish. We employed previously estimated growth parameters to run a yield per recruit model and analyse scenarios changing the values of the age of the first catch (Tc), natural mortality (M), and fishing mortality (F). Our model indicated an occurrence of overfishing because the fishing effort applied to catch peacock in Lago Grande at Manacapuru is greater than that associated with the maximum sustainable yield. In addition, the actual size of the first catch is almost half of the estimated value. Although there are difficulties in enforcing a minimum size of the catch, our results show that an increase in the size of the first catch to at least $25 \mathrm{~cm}$ would be a good strategy for management of this fishery.
\end{abstract}

Keywords: sustainable yield, overfishing, floodplain lakes, tucunaré, Rio Amazonas.

\section{Rendimento por recruta do tucunaré Cichla monoculus capturado no Lago Grande de Manacapuru}

\begin{abstract}
Resumo
O estudo avaliou o estoque de tucunaré Cichla monoculus capturados por uma frota de pesca de pequena escala no Lago Grande de Manacapuru. A série de dados foi composta por amostragens mensal de 200 peixes medidos a partir de fevereiro de 2007 a janeiro de 2008. Medimos comprimento padrão (cm) e peso total (gr) de cada peixe. Foram utilizados os parâmetros de crescimento, estimados em outro estudo pelos autores, para executar um modelo de rendimento por recruta e fazer cenários alterando os valores de idade de primeira captura $(\mathrm{Tc})$, taxa de mortalidade natural (M) e mortalidade por pesca (F). Com base nos resultados do modelo de rendimento por recruta, esta espécie está sofrendo sobrepesca de recrutamento, pois os valores atuais de esforço de pesca no Lago Grande de Manacapuru são excessivos e acima do correspondente ao rendimento máximo sustentável, e o tamanho real da primeira captura é quase metade do valor estimado. Apesar de reconhecidas dificuldades associadas com a aplicação de um limite de tamanho, nossos resultados indicam que um aumento do tamanho da primeira captura, pelo menos, para $25,0 \mathrm{~cm}$, poderia ser uma estratégia satisfatória para o manejo desta espécie.
\end{abstract}

Palavras-chave: rendimento sustentável, sobrepesca, lagos de várzea, tucunaré, Rio Amazonas.

\section{Introduction}

The peacock bass Cichla is an important natural resource in many regions of South America because of their natural abundance, sporting nature, and quality of flesh (Jepsen et al., 1999). The genus is widely distributed in the Amazon, Tocantins, Orinoco River Basins and in smaller rivers draining the Guianas Plateau toward the Atlantic Ocean (Kullander and Ferreira, 2006). The common name for some species of Cichla is tucunare in the Amazon

region, pavón in Venezuela, toekoenali in Suriname, and lukanani in Guyana (Kullander, 2003). Some species of this group are among the major food and fish game in South America. Cichla monoculus is one of the three Cichla species preferred by anglers in the Amazon Basin, mainly in the blackwater rivers. However, the intensity of fishing exploitation is unknown and could be high, as the stocks of this species are simultaneously exploited by subsistence, 
commercial, and sporting fisheries (less intensity) in the Rio Solimões and other whitewater rivers.

In addition to the importance of Cichla as a fishing resource, there are few studies on the population dynamics and actual status of its stocks. Jepsen et al. (1999) employed the bone structures (otoliths) to estimate the age and growth curve parameters of three species of this genus, $C$. orinocencis, $C$. intermedia, and $C$. temensis, caught in the rivers and reservoirs of Venezuela. Gomiero and Braga (2003) estimated the weight and length relationship for Cichla cf. ocellaris and C. monoculus caught in the Volta Grande Reservoir, located in southeast Brazil, a region in which this species was introduced. Holley et al. (2008) developed an analysis for Cichla temensis of the middle portion of Rio Negro and estimated the age, longevity, growth parameters and natural mortality of the fish. Campos and Freitas (2010) estimated the parameters of the von Bertalanffy growth curve of the peacock bass C. monoculus caught in Lago Grande at Manacapuru, located on the left banks of Rio Solimões.

However, the status of the C. monoculus stocks in Lago Grande at Manacapuru has never been estimated. Because the optimum value of exploitation could change due to environmental conditions, with consequences to the management strategy implemented, we believe that an estimate of the exploitation status should be useful as a reference point for the management of this species. In this work, we used the growth parameters estimated by Campos and Freitas (2010) to run a yield per recruit model and devised scenarios by changing the values of the age of the first catch and natural mortality.

\section{Material and Methods}

A series of length data were collected in the main harbour of the fishing landing of Manacapuru, a town with approximately 80,000 inhabitants and located on the left banks of the Rio Solimões (see Figure 1). The majority of the fish caught in Lago Grande is landed in the harbour called Panairzinha. These landings are typically from a commercial small-scale fishery and developed by the use of more than one type of fishing gear. The data series was composed of monthly samplings of 200 fish from February 2007 to January 2008. We measured the standard length (centimetres) and total weight (grams) of each fish.

Campos and Freitas (2010) estimated the following growth parameters of the von Bertalanffy equation and using the same data: $\mathrm{L}_{\infty}=53.55 \mathrm{~cm}, \mathrm{k}=0.38$. year $^{-1}$ and $\mathrm{A}_{0.95}=7.88$ years. The parameter $\mathrm{t}_{0}$ was considered zero because the initial size of the individual is negligible and because this parameter has no biological relevance.

The ages of recruitment ( $\mathrm{Tr}$ ) (Equation 1) and first catch (Tc) (Equation 2) were estimated using an adaptation of the von Bertalanffy growth equation (King, 1995; Sparre and Venema, 1997), as follows:

$$
\operatorname{Tr}=\mathrm{t}_{0}-\left(\frac{1}{\mathrm{k}}\right) * \mathrm{Ln} *\left[1-\frac{\mathrm{Lt}}{\mathrm{L} \infty}\right]
$$

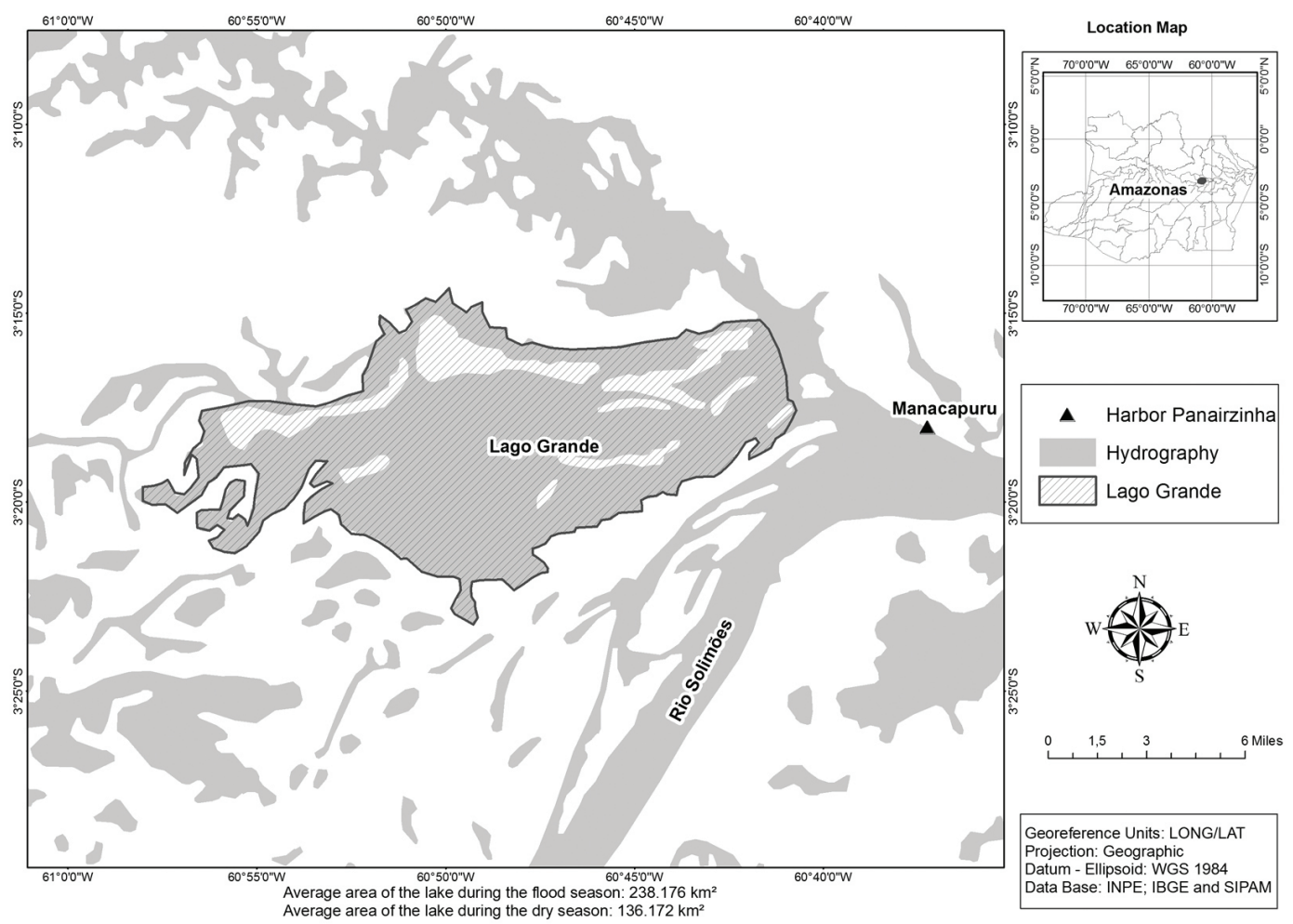

Figure 1. Lago Grande at Manacapuru, Rio Solimões and landing harbour location. 
$\mathrm{Tc}=\mathrm{t}_{0}-\left(\frac{1}{\mathrm{k}}\right) * \mathrm{Ln} *\left[1-\frac{\mathrm{Lt}}{\mathrm{L} \infty}\right]$.

The length of the first catch and mean length of recruitment were estimated assuming that

$\mathrm{Lc}=\mathrm{Lr}=$ The smallest length class fully in the sampling (King, 1995; Sparre and Venema, 1997).

The parameters "a" and "b" of the weight and length relationship, as defined by the equation $\mathrm{W}=\mathrm{a}^{*} \mathrm{~L}^{\mathrm{b}}$, where $\mathrm{W}$ is the total weight and $\mathrm{L}$ is the standard length, were estimated employing a non-linear model using the LevenbergMarquardt procedure.

The natural mortality $(\mathrm{M})$ was estimated by two equations:

- Taylor (1958), as described in Sparre and Venema (1997), which first estimates the longevity (Equation 3):

$\mathrm{A}_{0.95}=\mathrm{t}_{0}+\frac{2.996}{\mathrm{k}}$

and then the natural mortality (Equation 4):

$$
\mathrm{M}=\frac{-\ln (1-0.95)}{\mathrm{A}_{0.95}}
$$

, where $\mathrm{A}_{0.95}=$ the longevity, $\mathrm{t}_{0}=$ the parameter of the von Bertalanffy curve, and $\mathrm{k}=$ the intrinsic rate of growth (obtained from the von Bertalanffy curve).

- Pauly (1983), which estimates the natural mortality using an empiric equation (Equation 5) that establishes a relationship between the natural mortality, growth parameters, and the temperature at the water surface.

$$
\begin{aligned}
& \log \mathrm{M}=-0.0066-0.279 * \log \mathrm{L} \infty+ \\
& 0.6543 * \log \mathrm{k}+0.4634 * \log \mathrm{T}
\end{aligned}
$$

where $\mathrm{L} \infty$ and $\mathrm{k}=$ the parameters of the von Bertalanffy growth equation and $\mathrm{T}=$ the mean annual temperature at the water surface.

The total mortality $(Z)$ was estimated by the linearised catch curve (King, 1995), assuming that the stock density decreases by a rate proportional to the abundance of each age class. The age $(t)$ was estimated using the equation $\mathrm{t}=-\ln \left(1-\mathrm{Lt} / \mathrm{L}_{\infty}\right) / \mathrm{k}$. We assumed that $\mathrm{Z}$ is the slope of the regression between the log-transformed values of density and age.

The fishing mortality $(\mathrm{F})$ was estimated using $\mathrm{F}=\mathrm{Z}-\mathrm{M}$.

The yield per recruit curve was fitted to the model proposed by Beverton and Holt (1957) (Equation 6), as described in Sparre and Venema (1997):

$$
\begin{aligned}
& \frac{\mathrm{Y}}{\mathrm{R}}=\mathrm{F} * \exp [-\mathrm{M} *(\mathrm{Tc}-\mathrm{Tr})] * \mathrm{~W} \infty * \\
& {\left[\left(\frac{1}{\mathrm{Z}}\right)-\left(\frac{3 \mathrm{~S}}{\mathrm{Z}+\mathrm{K}}\right)+\left(\frac{3 \mathrm{~S}^{2}}{\mathrm{Z}+2 \mathrm{~K}}\right)-\left(\frac{3 \mathrm{~S}^{3}}{\mathrm{Z}+3 \mathrm{~K}}\right)\right]}
\end{aligned}
$$

where $\mathrm{Y} / \mathrm{R}=$ the yield per recruit ( $\mathrm{g} /$ recruit); $\mathrm{F}=$ the fishing mortality; $\mathrm{M}=$ the natural mortality; $\mathrm{Tr}=$ the age of recruitment; $\mathrm{Tc}=$ the age of the first catch; $\mathrm{W} \infty=$ the maximum theoretical weight; $\mathrm{Z}=$ the total mortality; $\mathrm{S}=\exp [-\mathrm{k} *(\mathrm{Tc}-\mathrm{t} 0)] ; \mathrm{k}=$ the intrinsic rate of growth and $\mathrm{t}_{0}=$ the parameter of the von Bertalanffy equation.

We changed the values of the age of the first catch and natural mortality to obtain scenarios of the yield per recruit of Cichla monoculus. The first parameter could be controlled by fishing management, and the second one is related to environmental changes.

\section{Results}

Table 1 shows the results of the parameters estimated.

Using the estimate of the natural mortality of 0.38 year $^{-1}$, we obtained an estimate of the maximum sustainable yield (MSY) of 375.60 gr.recruit $^{-1}$ for a fishing mortality (F) equal to 0.52.year-1, which is smaller than the actual levels of exploitation (Figure 2). By the estimate generated by the Taylor equation $\left(\mathrm{M}=0.80\right.$ year $\left.^{-1}\right)$, the maximum sustainable yield was 210.79 gr.recruit $^{-1}$ for a fishing mortality of 1.12 gr.recruit $^{-1}$ (see Figure 2).

The maximum sustainable yield (MSY) is quite sensitive to changes in the age of the first catch (Tc). Using the natural mortality rate estimated by Pauly's equation, our data showed that a reduction in approximately $60 \%$

\begin{tabular}{|c|c|}
\hline Total mortality $(Z)\left(\right.$ year $\left.^{-1}\right)$ & 2.22 \\
\hline Natural mortality $(\mathrm{M})\left(\text { year }^{-1}\right)^{\text {Taylor's equation }}$ & 0.38 \\
\hline Natural mortality (M) (year-1 $)^{\text {Pauly's equation (1980) }}$ & 0.80 \\
\hline Fishing mortality $(\mathrm{F})\left(\text { year }^{-1}\right)^{\text {Taylor's equation }}$ & 1.83 \\
\hline Fishing mortality $(F)\left(\text { year }^{-1}\right)^{\text {Pauly's equation }}$ & 1.42 \\
\hline Maximum Theoretical weight $\left(\mathrm{W}_{\infty}\right)(\mathrm{g})$ & 3290.70 \\
\hline Age of the first catch (Tc) (year) & 1.15 \\
\hline Length of the first catch $(\mathrm{Lc})(\mathrm{cm})$ & 19 \\
\hline Age of recruitment (Tr) (year) & 1.15 \\
\hline Length of recruitment $(\mathrm{Lr})(\mathrm{cm})$ & 19 \\
\hline
\end{tabular}
in the Tc, should result in a reduction of $40 \%$ of the MSY

Table 1. Population parameters of peacock bass (Cichla monoculus) caught at Lago Grande at Manacapuru (Brazil) between 2007 and 2008 .

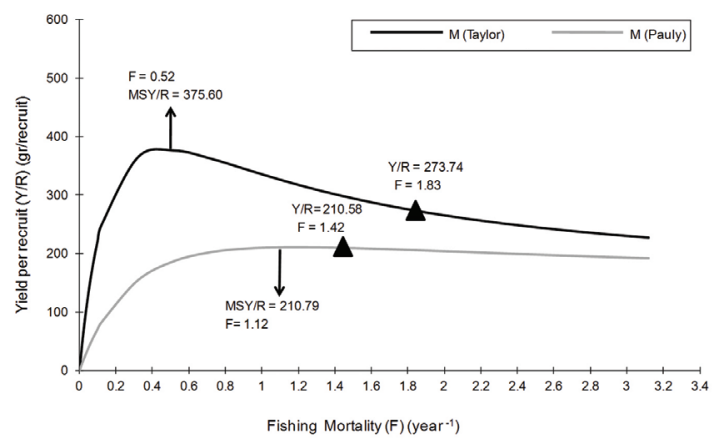

Figure 2. Yield per recruit for (Cichla monoculus) as a function of the fishing mortality (F) using the values of natural mortality $(\mathrm{M})$, as estimated by the equations of Taylor $\left(\mathrm{M}=0.38\right.$ year $\left.^{-1}\right)$ and Pauly $\left(\mathrm{M}=0.80\right.$ year $\left.^{-1}\right)$. 


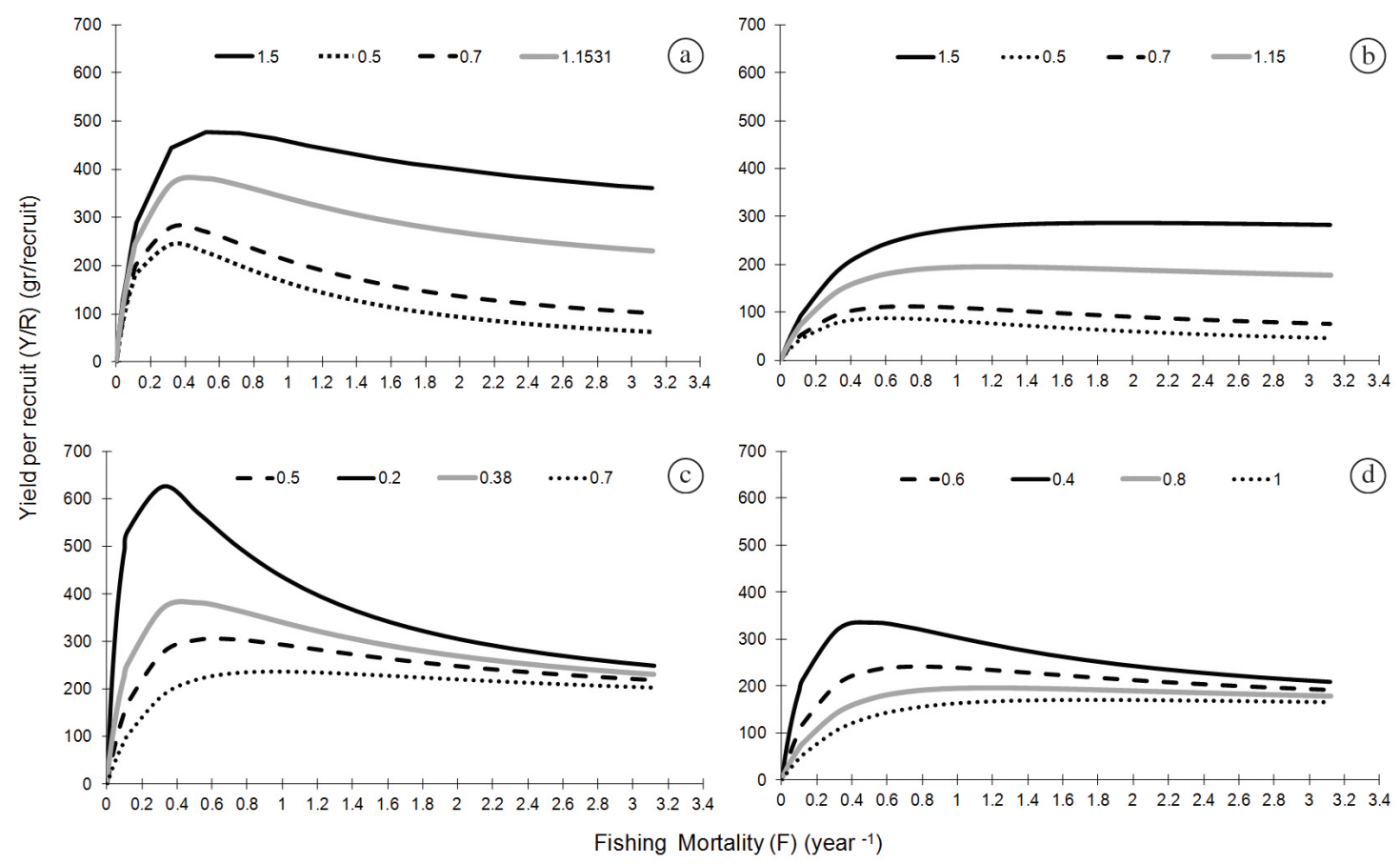

Figure 3. Yield per recruit of peacock bass (Cichla monoculus) by employing different values of the age at the first capture (Tc) with: natural mortality $\left(\mathrm{M}=0.38\right.$ year $\left.^{-1}\right)$ and fishing mortality $\left(\mathrm{F}=1.83\right.$ year $\left.^{-1}\right)$ estimated using Taylor's equation ( $\left.3 \mathrm{a}\right)$; natural mortality $\left(\mathrm{M}=0.80\right.$ year $\left.^{-1}\right)$ and fishing mortality $\left(\mathrm{F}=1.42\right.$ year $\left.^{-1}\right)$ estimated using Pauly's equation ( $\left.3 \mathrm{~b}\right)$; Yield per recruit by employing different values of the natural mortality $(\mathrm{M})$ in comparison with the values estimated using: Taylor's equation (3c) and Pauly's equation (3d).

(see Figure 3a). This same pattern was observed when the natural mortality rate was estimated using Taylor's equation (see Figure 3b), but the values of the MSY were consistently smaller than when the natural mortality rate was obtained using Pauly's equation.

The fish length associated with the age of the first catch ( $\mathrm{Tc}=1.5$ years) that resulted in the highest maximum sustainable yield was $23.26 \mathrm{~cm}$. The two scenarios of yield per recruit using the two estimates of natural mortality (see Figure $3 \mathrm{c}$ and $3 \mathrm{~d}$ ) exhibited the same pattern.

\section{Discussion}

The yield per recruit models are useful approaches for the evaluation of the status of fishing stocks and are important tools for the management of exploited fish populations (Sparre and Venema, 1997). Besides its large application, the Beverton and Holt (1956) model as the basis for the management of multispecific tropical fisheries has been criticised due to the complexity of the intra-specific interactions in these environments (Pauly, 1979).

Nevertheless, the peacock bass C. monoculus is a top predator, and its fishing is accomplished by the employment of very selective fishing gear, including tridents, hooklines, and bows and arrows. The use of gillnets results in sporadic catches, which are more frequent in whitewater rivers due to the visual ability of this species to avoid the fishing gear. We assumed that the effects of the biotic interactions could be neglected, with few effects on the analysis, and we believe that these results could be a first insight in the evaluation of the status of the peacock bass stocks in Lago Grande at Manacapuru, an important fishing ground of the lower stretch of Rio Solimões.

As evidence of overfishing occurrence, the fishing effort applied to the peacock bass stocks of Lago Grande at Manacapuru was consistently higher than the optimum effort associated with the maximum sustainable yield. The same pattern of overfishing for the peacock bass stocks was estimated by Bezerra-Silva et al. (1980) in a small reservoir in Northeast Brazil. Other stocks of Amazonian fishes have also been reported to be overfished, such as the stocks of tambaqui landed at Manaus (Merona and Bittencourt, 1988; Garcez and Freitas, 2011) and caught in the lower stretch of the Amazon River (Isaac and Ruffino, 1996).

The natural mortality rate $(\mathrm{M})$ is a sensitive parameter of the Beverton and Holt model (King, 1995). In general, stocks with low natural mortality rates are unable to support high fishing efforts before reaching the maximum sustainable yield. Additionally a low natural mortality is associated with a low growth rate. Ruffino and Isaac (1999) studied the population dynamics of Pseudoplatystoma tigrinum at the mean stretch of Rio Amazonas and concluded that this species showed low values of growth and natural mortality rates. Thus, the high fishing mortality observed was assumed to indicate overexploitation. The similar pattern observed for Cichla monoculus in Lago Grande at 
Manacapuru could be an indication that this is a common pattern for top predators.

Our study concluded that the current values of the fishing effort in Lago Grande at Manacapuru are excessive and above the corresponding maximum sustainable yield. Furthermore, the actual size of the first catch is almost half of the $\mathrm{L}_{50}$ of $35.0 \mathrm{~cm}$, as estimated by Ruffino and Isaac (2000). Although there are recognised difficulties associated with the enforcement of a size limit, our results indicated that an increase of the size of the first catch at least to $25.0 \mathrm{~cm}$, the size established by the Brazilian government, could be a good strategy for the management of this species.

\section{References}

BEVERTON, RJH. and HOLT, SJ., 1957. On the dynamics of exploited fish populations. London: Chapman and Hall. 535 p.

BEZERRA-SILVA, JW., CHACON, JO., SANTOS, EP., MELLO, JTC. and DUARTE, EA., 1980. Curva de rendimento do tucunaré pinima, Cichla temensis (Humboldt, 1833), do açude público "Estevam Marinho" (Curemas, Paraíba, Brasil) (Pisces, Actinopterygii, Cichilidae). Revista Brasileira de Biologia = Brazilian Journal of Biology, vol. 40, no. 1, p. 203-206.

CAMPOS, CP. and FREITAS, CEC., 2010. Curva de crescimento do tucunaré Cichla monoculus Spix \& Agassiz, 1831 do Lago Grande de Manacapuru, Amazonas, Brasil. Revista Brasileira de Engenharia de Pesca, vol. 5, no. 1, p. 1-9.

GARCEZ, CSR. and FREITAS, CEC., 2011. Seasonal catch distribution of tambaqui (Colossoma macropomum), Characidae in a central Amazon floodplain lake: implications for sustainable fisheries management. Journal of Applied Ichthyology, vol. 27, no. 1, p. 118-121. http://dx.doi.org/10.1111/j.1439-0426.2010.01521.x

GOMIERO, LM. and BRAGA, FMS., 2003. Relação pesocomprimento e fator de condição para Cichla cf. ocellaris e Cichla monoculus (Perciformes, Cichlidae) no reservatório de Volta Grande, rio Grande - MG/SP. Acta Scientiarum: Biological Sciences, vol. 25 , no. 1 , p. $79-86$.

HOLLEY, MH., MACEINA, MJ., THOMÉ-SOUZA, M. and FORSBERG, BR., 2008. Analysis of the trophy sport fishery for the speckled peacock bass in the Rio Negro River, Brazil. Fisheries Management and Ecology, vol. 15, no. 2, p. 93-98. http://dx.doi. org/10.1111/j.1365-2400.2007.00587.x
ISAAC, VJ. and RUFFINO, ML., 1996. Population dynamics of tambaqui, Colossoma macropomum Cuvier, in the Lower Amazon, Brazil. Fisheries Management and Ecology, vol. 3, no. 4, p. 315-333. http://dx.doi.org/10.1046/j.1365-2400.1996.d01-154.x

JEPSEN, DB., WINEMILLER, KO., TAPHORN, DC. and RODRIGUEZ-OLARTE, D., 1999. Age structure and growth of peacock cichlids from rivers and reservoirs of Venezuela. Journal of Fish Biology, vol. 55, p. 433-450. http://dx.doi. org/10.1111/j.1095-8649.1999.tb00689.x

KING, M., 1995. Fisheries biology, assessment and management. Oxford: Fishing New Books.

KULLANDER, SO., 2003. Family Cichlidae (Cichlids). In REIS, RE., KULLANDER, SO. and FERRARIS, CJ. (Eds.). Check list of the freshwater fishes of South and Central America. Porto Alegre: EdiPUCRS. p. 605-656.

KULLANDER, SO. and FERREIRA, EJG., 2006. A review of the South American cichlid genus Cichla, with descriptions of nine new species (Teleostei: Cichlidae). Ichthyological Explorations of Freshwaters, vol. 17, no. 4, p. 289-398.

MERONA, B. and BITTENCOURT, MM., 1988. A pesca na Amazônia através dos desembarques no mercado de Manaus: resultados preliminares. Memória Sociedad Ciências Natutales La Salle, vol. 48, suplemento 2, p. 433-453.

PAULY, D., 1979. Theory and management of tropical multispecies stocks: a review with emphasis on the Southeast Asian demersal fisheries. ICLARM Studies and Reviews, vol. 1, p. 1-35.

PAULY, D., 1983. Some simple methods for the assessment of tropical fish stocks. Rome: FAO. p. 1-52. FAO Fisheries Technical Paper no. 234.

RUFFINO, ML. and ISAAC, VJ., 1999. Dinâmica populacional do surubim-tigre Pseudoplatystoma tigrinum (Valeciennes, 1840) no Médio Amazonas (Siluriformes, Pimelodidae) . Acta Amazonica, vol. 29 , no. 3 , p. $463-476$.

RUFFINO, ML. and ISAAC, VJ., 2000. Ciclo de vida e parâmetros biológicos de algumas espécies da Amazônia brasileira In RUFFINO, ML. Recursos pesqueiros no Médio Amazonas: biologia e estatística pesqueira. Brasília: IBAMA. p. 11-30.

SPARRE, P. and VENEMA, SC., 1997. Introdução à avaliação de mananciais de peixes tropicais. Roma: FAO. Documento Técnico Sobre as Pescas no. 306/1.

TAYLOR, CC., 1958. Water temperature and Cod Growth-Rate Cod growth and temperature. Journal Du Conseil, vol. 23, no. 3, p. 366-370. http://dx.doi.org/10.1093/icesjms/23.3.366 